\title{
THE PREPARATION OF FUTURE TEACHERS: MODERN APPROACHES TO LEARNING
}

\author{
Iryna Khalymon \\ ORCID iD 0000-0003-4815-751X \\ PhD (Pedagogy), Associate Professor of Applied Linguistics Department, \\ Nizhyn Mykola Gogol State University \\ 2 Hrafska Str., 16600 Nizhyn, Ukraine \\ irene.khalymon@gmail.com
}

\section{Svitlana Shevchenko}

ORCID iD 0000-0002-9110-2496

$\mathrm{PhD}$ (Pedagogy), Associate Professor of Germanic Philology and

Foreign Languages Methodology Department,

Nizhyn Mykola Gogol State University

2 Hrafska Str., 16600 Nizhyn, Ukraine

svetusikndu@gmail.com

https://doi.org/10.28925/2518-7635.2020.5.2

\section{ABSTRACT}

The article is devoted to the issue of approaches to learning used by prospective teachers. The key difference between two main approaches to learning - deep and surface - lies in the intention or absence of intention to understand the material. Deep approach to learning is likely to result in a high level of understanding and better learning outcomes while surface approach leads to ineffective learning. Understanding students' approaches to learning helps adjust teaching strategies for more effective learning. The purpose of the article is to identify the approaches to learning used by prospective teachers and consider the implications for teacher trainers. The article reports findings of a survey study into the approaches to learning used by prospective teachers of the Ukrainian language and literature mastering English as a specialism at a Ukrainian university. The main research tool was a questionnaire consisting of twenty statements. Ten statements concerning deep approach include such aspects as deep approach per se, relating ideas, use of evidence, intrinsic motivation. The other ten statements relate to surface approach and include such subscales as surface approach proper, syllabus boundness, fear of failure, extrinsic motivation. The respondents were asked to express how much they agreed with the statements using Likert scale. The data were analysed to find out mean scores and standard deviation. The findings demonstrate that students employ both approaches almost equally intensely: the mean scores of the Deep Learning Approach and the Surface Learning Approach scales are 3.64 and 3.34 correspondingly. However, according to the evaluation criteria the figures fall into different categories: deep approach 
has a high level of prevalence while surface approach has a moderate one. Basing on the obtained results, the authors suggest that teacher trainers should pay more attention to promoting deep learning approach through applying effective instructional strategies which improve the quality of learning; fostering students' personal interest in learning; changing the focus of the assessment system from reproducing to understanding.

Key words: approach to learning, deep approach to learning, prospective teacher, student, surface approach to learning.

(c) Iryna Khalymon, Svitlana Shevchenko, 2020

\section{INTRODUCTION}

Teacher's profession is one of the most important in the world as teachers are responsible for the education of the younger generation, i.e. they are building the future of the world. It is teachers' skills, abilities, professionalism that the final result depends on. Therefore teacher-training institutions should work hard to provide high-quality education of prospective teachers. A number of researchers point out that the quality of learning outcomes is affected by students' approach to learning and the study skills they use (Marton \& Saljo, 1976; Entwistle \& Ramsden, 1983; Biggs, 1987). It is therefore vital that prospective teachers use effective approaches and study skills in their learning.

As N. Nordin, R.A. Wahab \& N.A. Dahlan (2013) observe, understanding prospective teachers' approaches to learning could provide a useful insight to planning and designing effective instructional strategies to facilitate learning. For this reason, investigating the approaches to learning of prospective teachers is very important. In Ukraine to date research on approaches to learning used by university students in general and prospective teachers in particular is limited, so it seems important to fill in the gap. Accordingly, the purpose of this article is to identify the approaches to learning used by prospective teachers and consider the implications for teacher trainers.

\section{UNDERSTANDING APPROACHES TO LEARNING}

Approach to learning is understood as the nature of the relationship between the student, context and task (Biggs, Kember \& Leung, 2001). Students' approaches to learning have been in the focus of researchers' attention since 1970s when F. Marton and R. Saljo (1976) conducted early research based on text reading experiments. They identified two levels of processing of learning deep and surface, the main difference between them being the intention or the absence of intention to understand. Their ideas were later developed in a number of studies (Biggs, 1987; Entwistle \& Ramsden, 1983; Richardson, 1994).

According to N. Entwistle and P. Ramsden (1983) students using deep learning approach try to understand the main idea, meaning in the materials 
they are studying and relate it to their previous knowledge or experience. They critically analyse the arguments and evidence in relation to their prior knowledge and other resources. Besides, they tend to be intrinsically motivated, enjoy learning and apply the acquired knowledge to the real world. In contrast, learners who prefer surface approach are inclined to minimize the use of their intellectual capacity, avoid personal understanding. They use different forms of rote learning and tend to reproduce the learning material by word in a test or exam rather than actually understand it. Being constrained by the specific learning task, they do not go beyond it. Students applying surface approach are likely to be extrinsically motivated, and predominant motivation is fear of failure and concern with the completion of a course.

Researchers assert that deep approach to learning is more likely to result in a high level of understanding and effective learning whereas surface approach is likely to lead to a low level of understanding and ineffective learning (Trigwell \& Prosser, 1991). Surface approach, however, is not always that bad. Some researchers argue that surface learning strategies are necessary for further acquiring of deeper knowledge in certain fields of study (e.g. languages, mathematics and the sciences) and in specific contexts, for developing deep learning capabilities (Hattie \& Donoghue, 2016; Ryan \& Louie, 2007).

Learning approaches, however, are not stable traits of learners. Though some students are more likely to use deep approach while others tend to use surface approach, in general learners may adopt different approaches in different learning contexts (Biggs, 1987, p. 93). It is suggested that factors like "good teaching», «clear goals and standards», suitable «assessments», encouragement towards autonomous «learning» and quality feedback also promote using deep learning strategies (Wang, 2013, pp. 33-34, as cited by Desierto, Maio, O'Rourke \& Sharp, 2018).

\section{ORGANIZATION}

The study was conducted in the form of survey and is based on quantitative research. The main research tool was a shortened and adapted version of the Approaches to Studying Inventory originally developed by N. Entwistle \& P. Ramsden. It is reported that the scale has been piloted and its homogeneity and validity demonstrated by means of statistical tools (Swatevarcharkul, p. 51). Items 1-10 of the questionnaire concern the components of deep approach: deep approach per se (Items 1-3); relating ideas (Items 4-6), use of evidence (Items 7, 8) and intrinsic motivation (Items 9, 10). The other 10 items relate to the components of surface approach: surface approach per se (Items 11-14), syllabus boundness (Items 15, 16), fear of failure (Items 17, 18), extrinsic motivation (Items 19, 20). The respondents, however, were not informed of these categories.

As the aim of the research is to measure people's attitudes and beliefs, Likert Scale was used to collect the attitudinal data through getting reactions to statements. Students were asked to rate how much they agreed with each 
statement. For scoring purposes the options «strongly agree», «agree», «uncertain», «disagree», «strongly disagree» are given weights of 5, 4, 3, 2, 1 respectively. The "weights» are interpreted as follows: 5 means very high prevalence of the approach, 4 - high, 3 - moderate, 2 - low, 1 - very low. Correspondingly, the evaluation criteria of the questionnaire are as follows: up to 1.50 means that the approach has very low prevalence, 1.51-2.50 - low, 2.51-3.50 - moderate, 3.51-4.50 - high, 4.51-5.00 - very high.

The research was carried out with a group of prospective teachers of the Ukrainian language and literature minoring in English at the Educational and Research Institute of Philology, Translation and Journalism of Nizhyn Mykola Gogol State University. The questionnaire was completed by 45 respondents studying in the $3^{\text {rd }}$ and $4^{\text {th }}$ years of Bachelor's programme and in the $1^{\text {st }}$ year of Master's programme (10,11 and 24 students respectively). The questionnaire was completed by the respondents in class and was anonymous.

The survey response data were tabulated using Microsoft Excel 2010. The results are displayed in Tables 1 and 2. For the convenience of presentation the five options of responses were reduced to three categories - disagreement, uncertainty and agreement, i.e. in the tables column «D» presents options «strongly disagree» and «disagree», column «U» - option «uncertain», column «A» - options «strongly agree» and «agree». The numbers in these columns present percentages of responses. The data were also analysed to find out mean score and standard deviation (columns «M» and «SD» in the tables).

\section{FINDINGS AND DISCUSSION}

The findings (see Tables 1 and 2) reveal that on average students employ both deep and surface learning approaches almost equally intensely: the mean of the Deep Learning Approach scale is $3.64(\mathrm{SD}=0.90)$ and the mean of the Surface Learning Approach scale is $3.34(\mathrm{SD}=0.98)$. The difference between the mean scores is not so big, nevertheless it is significant enough as according to the criteria mentioned above the first score falls into the «high» category whereas the latter belongs to the «moderate» range. This means that on average deep learning approach has a high level of prevalence while surface learning approach has a moderate level of prevalence.

Table 1

Mean of Each Item of Deep Approaches to Learning

\begin{tabular}{|l|c|c|c|c|c|c|}
\hline \multicolumn{1}{|c|}{ Items } & $\mathrm{D}$ & $\mathrm{U}$ & $\mathrm{A}$ & $\mathrm{M}$ & $\mathrm{SD}$ & Meaning \\
\hline $\begin{array}{l}\text { 1. I usually set out to understand thoroughly } \\
\text { the meaning of what I am asked to learn. }\end{array}$ & 11.11 & 42.22 & 46.67 & 3.47 & 0.91 & Moderate \\
\hline $\begin{array}{l}\text { 2. I often find myself questioning things that I } \\
\text { hear in lectures or read in books. }\end{array}$ & 4.44 & 42.22 & 53.33 & 3.56 & 0.68 & High \\
\hline $\begin{array}{l}\text { 3. I generally put a lot of effort into trying } \\
\text { to understand things which initially seem } \\
\text { difficult. }\end{array}$ & 13.33 & 42.22 & 44.44 & 3.51 & 0.96 & High \\
\hline
\end{tabular}




\begin{tabular}{|l|c|c|c|c|c|c|}
\hline \multicolumn{1}{|c|}{ Items } & $\mathrm{D}$ & $\mathrm{U}$ & $\mathrm{A}$ & $\mathrm{M}$ & $\mathrm{SD}$ & Meaning \\
\hline Deep Approach & $\mathbf{9 . 6 3}$ & $\mathbf{4 2 . 2 2}$ & $\mathbf{4 8 . 1 5}$ & $\mathbf{3 . 5 1}$ & $\mathbf{0 . 8 5}$ & High \\
\hline $\begin{array}{l}\text { 4. I try to relate ideas in one subject to those } \\
\text { in others. }\end{array}$ & 13.33 & 22.22 & 64.44 & 3.84 & 1.15 & High \\
\hline $\begin{array}{l}\text { 5. I need to read around a subject pretty widely } \\
\text { before I’m ready to put my ideas on paper. }\end{array}$ & 8.89 & 35.56 & 55.56 & 3.56 & 0.93 & High \\
\hline $\begin{array}{l}\text { 6. I find it helpful to «map out» a new topic } \\
\text { for myself by seeing how the ideas fit together. }\end{array}$ & 13.33 & 22.22 & 64.44 & 3.58 & 0.88 & High \\
\hline Relating Ideas & $\mathbf{1 1 . 8 5}$ & $\mathbf{2 6 . 6 7}$ & $\mathbf{6 1 . 4 8}$ & $\mathbf{3 . 6 6}$ & $\mathbf{0 . 9 9}$ & High \\
\hline $\begin{array}{l}\text { 7. When I'm reading an article, I generally } \\
\text { examine the evidence carefully to decide whether } \\
\text { the conclusion is justified. }\end{array}$ & 15.56 & 35.56 & 48.89 & 3.40 & 0.83 & Moderate \\
\hline $\begin{array}{l}\text { 8. I am usually cautious in drawing conclusions if } \\
\text { they are not well supported by evidence. }\end{array}$ & 8.89 & 44.44 & 46.67 & 3.49 & 0.81 & Moderate \\
\hline Use of Evidence & $\mathbf{1 2 . 2 2}$ & $\mathbf{4 0 . 0 0}$ & $\mathbf{4 7 . 7 8}$ & $\mathbf{3 . 4 5}$ & $\mathbf{0 . 8 2}$ & Moderate \\
\hline $\begin{array}{l}\text { 9. My main reason for being here is that I can } \\
\text { learn more about the subjects which really } \\
\text { interest me. }\end{array}$ & 15.56 & 13.33 & 71.11 & 3.87 & 1.02 & High \\
\hline $\begin{array}{l}\text { 10. I find that studying academic topics can often } \\
\text { be really exciting and interesting. }\end{array}$ & 4.44 & 13.33 & 82.22 & 4.11 & 0.80 & High \\
\hline Intrinsic Motivation & $\mathbf{1 0 . 0 0}$ & $\mathbf{1 3 . 3 3}$ & $\mathbf{7 6 . 6 7}$ & $\mathbf{3 . 9 9}$ & $\mathbf{0 . 9 1}$ & High \\
\hline Total & $\mathbf{1 0 . 8 9}$ & $\mathbf{3 1 . 3 3}$ & $\mathbf{5 7 . 7 8}$ & $\mathbf{3 . 6 4}$ & $\mathbf{0 . 9 0}$ & High \\
\hline
\end{tabular}

Let us analyse each subscale in detail. The subscale of Deep Approach per se has mean score of $3.51(\mathrm{SD}=0.85)$ which lies just above the moderate level of prevalence. The figures do not allow teacher trainers to be too optimistic as they demonstrate that in many learning situations the respondents have no intention to understand and critically analyze what they are learning.

All the mean scores in the subscale of Relating Ideas lie in the range between 3.50 and 3.70 which means that the attributes of deep approach to learning in this relation are manifested quite often by the majority of the respondents. Nevertheless, the responses are far from being unanimous, which implies that teacher trainers should put an extra effort into providing learning contexts which encourage these deep learning strategies.

Unlike other subscales of the Deep Learning Approach scale, the subscale Use of Evidence has mean score of $3.45(\mathrm{SD}=0.82)$ which characterizes a moderate level of prevalence. As the figures demonstrate, more than a half of the respondents either never or seldom critically examine the evidence and the conclusions based on it to decide if the conclusions are well justified. The responses also demonstrate a high degree of uncertainty. It can be inferred that critical thinking skills are either not well developed in the students or are not used by them in learning situations. This implies that teacher trainers should encourage learners to critically analyze the information, paying special attention to the evidence.

The results obtained in the subscale of Intrinsic Motivation reveal that students have a high level of intrinsic motivation with mean score of 3.99 $(\mathrm{SD}=0.91)$ being the highest among the other factors. No doubt, teacher trainers can depend on the learners' intrinsic motivation as a key factor encouraging deep learning approach. 
Table 2 demonstrates the data concerning surface approach to learning. Mean scores of most items lie in the range between 3.0 and 3.5, with the whole scale having mean score of $3.34(\mathrm{SD}=0.98)$, thus indicating that surface approach has a moderate level of prevalence. Only Items 12, 15 and 19 got mean scores which characterize a high level of surface approach prevalence. Thus, we can assert that surface approach to learning is less pronounced than the deep one.

Table 2

\section{Mean of Each Item of Surface Approach to Learning}

\begin{tabular}{|l|c|c|c|c|c|c|}
\hline \multicolumn{1}{|c|}{ Items } & $\mathrm{D}$ & $\mathrm{U}$ & $\mathrm{A}$ & $\mathrm{M}$ & $\mathrm{SD}$ & Meaning \\
\hline $\begin{array}{l}\text { 11. I usually don't have time to think about } \\
\text { the implications of what I have read. }\end{array}$ & 24.44 & 40.00 & 35.56 & 3.09 & 0.96 & Moderate \\
\hline $\begin{array}{l}\text { 12. When I'm reading, I try to memorise } \\
\text { important facts which may come in useful later. }\end{array}$ & 4.44 & 11.11 & 84.44 & 4.16 & 0.87 & High \\
\hline $\begin{array}{l}\text { 13. Often I find I have to read things without } \\
\text { having a chance to really understand them. }\end{array}$ & 28.89 & 33.33 & 37.78 & 3.13 & 0.96 & Moderate \\
\hline $\begin{array}{l}\text { 14. I find I have to concentrate on memorising } \\
\text { a good deal of what we have to learn. }\end{array}$ & 13.33 & 35.56 & 51.11 & 3.40 & 0.98 & Moderate \\
\hline Surface Approach & 17.78 & 30.00 & 52.22 & 3.45 & 0.94 & Moderate \\
\hline $\begin{array}{l}\text { 15. Ilike to be told precisely what to do in essays } \\
\text { or other assignments. }\end{array}$ & 11.11 & 35.56 & 53.33 & 3.51 & 1.02 & High \\
\hline $\begin{array}{l}\text { 16. I tend to read very little beyond what's } \\
\text { required for completing assignments. }\end{array}$ & 22.22 & 68.89 & 8.89 & 2.78 & 0.73 & Moderate \\
\hline Syllabus Boundness & 16.67 & 52.22 & 31.11 & 3.15 & 0.88 & Moderate \\
\hline $\begin{array}{l}\text { 17. The continual pressure of work assignments, } \\
\text { deadline and competition often makes me tense } \\
\text { and depressed. }\end{array}$ & 28.89 & 26.67 & 44.44 & 3.22 & 1.30 & Moderate \\
\hline $\begin{array}{l}\text { 18. A poor first answer in an exam makes me } \\
\text { panic and competition often makes me tense } \\
\text { and depressed. }\end{array}$ & 17.78 & 22.22 & 60.00 & 3.49 & 1.13 & Moderate \\
\hline Fear of Failure & 23.33 & 24.44 & 52.22 & 3.36 & 1.22 & Moderate \\
\hline $\begin{array}{l}\text { 19. I chose my present courses mainly to give me } \\
\text { a chance of a really good job afterwards. }\end{array}$ & 15.56 & 13.33 & 71.11 & 3.62 & 0.90 & High \\
\hline $\begin{array}{l}\text { 20. I suppose I am more interested } \\
\text { in the qualifications I'll get than in the courses } \\
\text { I'm taking. }\end{array}$ & 33.33 & 31.11 & 35.56 & 2.96 & 0.94 & Moderate \\
\hline Extrinsic Motivation & 24.44 & 22.22 & 53.33 & 3.29 & 0.92 & Moderate \\
\hline Total & $\mathbf{2 0 . 0 0}$ & $\mathbf{3 1 . 7 8}$ & $\mathbf{4 8 . 2 2}$ & $\mathbf{3 . 3 4}$ & $\mathbf{0 . 9 8}$ & Moderate \\
\hline
\end{tabular}

Let us analyse each subscale in detail. The first subscale, Surface Approach per se, has a moderate level of prevalence with mean score of $3.45(\mathrm{SD}=0.94)$. Item 12, however, has mean score of $4.16(\mathrm{SD}=0.87)$. As it can be seen from the table, $84.44 \%$ of the respondents, which is actually the highest percentage in the whole questionnaire, admitted that while reading they tried to memorise important facts which may come in useful later. The importance of memorization for the respondents is supported by the data concerning Item 14: $51.11 \%$ of prospective teachers noted that they had to concentrate on memorising a good deal of what they have to learn. These findings can be explained, on the one hand, by the specifics of the field of study, and, on the other hand, by reproductive learning which is still widely spread 
in Ukrainian educational establishments. It may seem really alarming that prospective teachers rely on memorization in their learning so much, as it can mean that their prevailing conception of learning is reproducing, and this is likely to impact their teaching practices in the future. However, K.C. Tang (1991, as cited in Kember, 2016) in her studies observes that memorization could be divided into surface and deep. She asserts that students may tend to employ a combination of understanding and memorizing approaches: they initially use deep approach to learning to understand the material but then switch to memorizing in order to obtain good marks as their courses and assessment system stress on reproduction. Thus, it can be concluded that memorization is not always that bad.

The data on Items 11 and 13 in this subscale are much more troubling though, as the figures demonstrate that more than a third of the respondents do not actually understand what they learn and do not have time to think about implications of what they have read. The latter may indicate that the students have excessive workload.

The subscale of Syllabus Boundness with mean score of $3.15(\mathrm{SD}=0.88)$ has a moderate level of prevalence. It's worth pointing out that more than a half of the respondents admit that they «like to be told precisely what to do in essays or other assignments» (Item 15). On the one hand, the desire to get clear instructions seems natural enough, but on the other hand, it can be inferred from these data that learners are devoid of initiative, they do not want to make an extra effort and learn something besides the compulsory task. Another figure of interest is the number of responses (68.89\%) to Item 16 falling into the category "Uncertain». This might imply that whether students do anything «beyond what's required for completing assignments» for the majority depends on the learning context or task.

The subscale of Fear of Failure also has moderate prevalence with mean score of $3.36(\mathrm{SD}=1.22)$. The data indicate that fear of failure is pronounced in more than a half of the respondents which is really discouraging. The fact that as many as $60 \%$ of them agreed that «a poor first answer in an exam made them panic» suggests drawbacks in the assessment system which is mainly based on reproducing the remembered material.

The subscale of Extrinsic Motivation has mean score of 3.29 ( $\mathrm{SD}=0.92$ ) which means that the students' level of extrinsic motivation is moderate. The data on Item 19, however, attract attention as it has mean score of 3.62 $(\mathrm{SD}=0.90)$, which indicates that it has a high level of prevalence. Traditionally, a high level of extrinsic motivation is regarded as a negative factor in learning. However, considering the economic situation in Ukraine, it cannot be denied that getting a good job after graduation is not important. So we suppose that this kind of extrinsic motivation is vital for learning as well and has rather positive than negative impact on the choice of approach to learning.

There is one more aspect in the data that attracts attention. In many cases a large per cent of answers falls into the category «Uncertain». Thus, 
more than a third of respondents chose this option responding to items 1,2 , $3,5,7,8$ in the domain of deep learning approach and items $11,13,14,15$, 16 in the domain of surface learning approach. This suggests that students' approaches to learning vary so much from context to context, from situation to situation that it is difficult for them to give some definite answer.

The findings can have several practical implications for teacher trainers. Firstly, educators should provide a learning environment where students develop a strong personal interest in learning because as K. Warburton (2003) argues, the first step in reaching deep learning approach is a high level of commitment with the learning subject, i.e. motivation to understand. As, researchers suggest, it can be reached by helping students change their conceptions of learning, facilitating understanding that learning is about developing meaning and understanding, fostering in them qualitative perception of learning (Dart et al., 2000). Thus, by promoting deep approach to learning, it is hoped that surface approach to learning can be reduced.

Secondly, the findings could provide a useful insight to planning and designing effective instructional strategies, creating experiences that could enhance the learning of participants because, as J.T.E. Richardson (2005) points out, desirable approaches to studying can be brought by appropriate course design, appropriate teaching methods, or appropriate forms of assessment. Thus, teacher trainers can promote deep approaches to learning through the creation of learning environments that students perceive as safe, supportive, and offering helpful relationships. They can also present opportunities for exploration, inquiry, and experimentation by providing problems to be solved (Ak, 2008).

Finally, as the choice of approach to learning depends on the nature of assessment, it can be inferred from the findings that the assessment system needs considerable change. Unfortunately, N. Entwistle's statement that current assessment and teaching seems to encourage reproductive form of learning (Entwistle, 1984, as cited in Nordin et al., 2013), is still true for the Ukrainian educational context. Consequently, as N. Nordin et al. (2013) suggest, development of learning assessment should move beyond a grade based learning outcome to more comprehensive, skills and hands-on based learning outcomes.

\section{CONCLUSIONS}

Investigating the prospective teachers' learning approaches contributes to better understanding of students' perceptions of learning and their needs. On the one hand, it is encouraging to know that the respondents tend to use deep learning approach, especially that they have a high level of intrinsic motivation. On the other hand, the study reveals that the students are almost equally inclined to use surface learning approach, which is especially vividly demonstrated by their inclination to memorize learning material. To further promote deep learning approach teacher trainers should seek ways to change teaching 
and assessment procedures and encourage critical thinking and conscious reflection on the content of learning material and the learning process itself.

As this study is intended to examine approaches to learning of a small group of prospective teachers at one university, it is neither comprehensive nor extensive. There are many more dimensions and pieces yet to be explored, such as the ways to promote deep learning approach, the correlation between learning approach and learner autonomy level, between teaching and learning approaches, between learning approach and learning outcomes, prospective teachers' conceptions of learning etc.

\section{REFERENCES}

Ak, Ş. (2008). A Conceptual Analysis on the Approaches to Learning. Educational Sciences: Theory and Practice, 8. Retrieved from: https://eric. ed.gov/?id=EJ837764 (eng.)

Biggs, J. B. (1987). Students approaches to learning and studying. Hawthorn: Australian Council for Educational Research. Retrieved from: https://eric. ed.gov/?id=ED308201 (eng).

Biggs, J., Kember, D., \& Leung, D.Y. (2001). The revised two-factor Study Process Questionnaire: R-SPQ-2F. British Journal of Educational Psychology, 71, 133-149. DOI: 10.1348/000709901158433 (eng).

Dart, B., Burnett, P., Purdie, N., Boulton-Lewis, G., Campbell, J., \& Smith, D. (2000). Students' Conceptions of Learning, the Classroom Environment, and Approaches to Learning. Journal of Educational Research, 93 (4), 262-270. DOI: 10.1080/00220670009598715 (eng).

Desierto, A., Maio, C.D., O’Rourke, J., \& Sharp, S. (2018). Deep or Surface? The learning approaches of enabling students in an Australian public university. Proceedings of STARS Conference 2018 (New Zealand) July 11, 2018. Retrieved from: https://ro.ecu.edu.au/ecuworkspost2013/5226/ (eng).

Entwistle, N. J., \& Ramsden, P. (1983). Understanding Student Learning. London: Croom Helm. Retrieved from: https://eric.ed.gov/?id=ED244959 (eng).

Hattie, J.A.C., \& Donoghue, G.M. (2016). Learning strategies: A synthesis and conceptual model. Science of Learning, 1 (16013), 1-13. DOI: 10.1038/ npjscilearn.2016.13. (eng).

Kember, D. (2016). Why do Chinese students out-perform those from the West? Do approaches to learning contribute to the explanation?. Cogent Education, 3 (1), 1248187. DOI: 10.1080/2331186X.2016.1248187 (eng).

Marton, F., \& Saljo, R. (1976). On qualitative differences in learning. I Outcome and process, British Journal of Educational Psychology, 46, 4-11. DOI: 10.1111/j.2044-8279.1976.tb02980.x (eng).

Nordin, N., Wahab, R.A., Dahlan, N.A. (2013). Approaches to Learning among Trainee Teachers: Malaysian Experiences. Procedia - Social and Behavioral Sciences, 105, 284-293. DOI: 105. 284-293. 10.1016/j.sbspro.2013.11.030. (eng). 
Richardson, J. (1994). Mature Students in Higher Education: I. A Literature Survey on Approaches to Studying. Studies in Higher Education, 19, 309-325. DOI: 10.1080/03075079412331381900 (eng).

Richardson, J.T.E. (2005). Students' Approaches to Learning and Teachers' Approaches to Teaching in Higher Education. Educational Psychology, 25 (6), 673-680. DOI: 10.1080/01443410500344720 (eng).

Ryan, J., \& Louie, K. (2007). False Dichotomy? 'Western' and 'Confucian' concepts of scholarship and learning. Educational Philosophy and Theory, 39 (4), 404-417. DOI: 10.1111/j.1469-5812.2007.00347.x (eng).

Swatevarcharkul, R. (2008). An investigation on readiness for learner autonomy, approaches to learning of tertiary students and the roles of English language teachers in enhancing learner autonomy in higher education: Research report. Dhurankij Pundit University. Retrieved from: http:/libdoc.dpu.ac.th/ research/134463.pdf (eng).

Trigwell, K., \& Prosser, M. (1991). Improving the quality of student learning: the influence of learning context and students approaches to learning on learning outcomes. Higher Education, 22, 251-266. DOI: 10.1007/ BF00132290

Warburton, K. (2003). Deep learning and education for sustainability, International Journal of Sustainability in Higher Education, 4 (1), 44-56. DOI: 10.1108/14676370310455332 (eng).

\section{ПІДХОДИ МАЙБУТНІХ УЧИТЕЛІВ ДО НАВЧАННЯ}

Халимон Ірина, кандидат педагогічних наук, доцент кафедри прикладної лінгвістики, Ніжинський державний університет імені Миколи Гоголя, вул. Графська, 2, 16600 Ніжин, Україна, irene.khalymon@gmail.com

Шевченко Світлана, кандидат педагогічних наук, доцент кафедри германської філології та методики викладання іноземних мов, Ніжинський державний університет імені Миколи Гоголя, вул. Графська, 2, 16600 Ніжин, Україна, svetusikndu@gmail.com

Стаття присвячена дослідженню підходів до навчання, щзо застосовуються майбутніми вчителями. 3'ясовано, щзо існує два основних підходи до навчання - глибокий $і$ поверховий. Головна відмінність між ними полягає у наявності або відсутності наміру зрозуміти матеріал, що вивчається. Глибокий підхід сприяє кращим результатам навчання, в той час як поверховий підхід призводить до неефективного навчання. Розуміння підходів до навчання, які використовуються студентами, необхідне для оптимізації викладання з метою отримання найкращих результатів. У статті представлено результати дослідження підходів до навчання майбутніх учителів украӥнської мови і літератури, які опановують 
спеціалізацію «Англійська мова». Дослідження здійснювалося шляхом анкетування. Анкета включала 20 тверджень, до яких респонденти повинні були висловити ставлення, користуючись шкалою Лікерта. Твердження щодо глибокого підходу охоплюють такі аспекти, як власне глибокий підхід, встановлення зв'язку між ідеями, використання доказів і внутрішня мотивачія. Твердження, що стосуються поверхового підходу, включають такі підикали як поверховий підхід сам по собі, обмеження програмою, страх невдачі, зовнішня мотивація. Дослідження виявило, що глибокий підхід до навчання має високий рівень почирення, а поверховий підхід середній. Грунтуючись на отриманих результатах, автори вважають, що викладачам слід приділяти більше уваги заохоченню студентів до використання глибокого підходу. Пропонується створювати навчальне середовища, яке сприяє виробленню в студентів особистісного зацікавлення в навчанні; використовувати в навчальному процесі технології й стратегіï, які покращують якість навчання, а також переносити бокус системи оцінювання з відтворення на розуміння матеріалу.

Ключові слова: глибокий підхід до навчання, майбутній учитель, підхід до навчання, поверховий підхід до навчання, студент.

Received: 30.06 .2020

Accepted: 26.11.2020 